\title{
The Physiotherapy Intervention for Shoulder Pain in Patients Treated for Breast Cancer: Systematic Review
}

\author{
Andrea Giacalone ${ }^{1}$, Paola Alessandria ${ }^{2}$, Enzo Ruberti ${ }^{3}$ \\ 1. Department of Industrial Engineering, University of Tor Vergata, Roma, ITA 2. Department of Physical Therapy, \\ University of Turin, Turin, ITA 3. Department of Neurology, Sapienza University, Roma, ITA
}

Corresponding author: Andrea Giacalone, giacalonericci@yahoo.it

\begin{abstract}
Pain and joint dysfunction of the upper limb following treatment for mammary carcinoma are defined as the most frequent side effects of surgery for mammary carcinoma by calculating a prevalence range in the USA that varies between $12 \%$ and $51 \%$ with regard to pain and between $1.5 \%$ and $50 \%$ for joint dysfunction. This objective of this study was to describe physiotherapy interventions that demonstrate efficacy based on the type of pain present in patients with shoulder pain who have been treated for breast cancer.
\end{abstract}

We conducted a search for relevant publications in the last 10 years (2009-2019) on the PubMed, Medline, CINAHL, and Cochrane databases. The articles obtained were selected on the basis of correlation criteria, with themes concerning shoulder pain after mammary carcinoma and physiotherapy performed to treat this pain.

Studies suggest treating musculoskeletal pain through active exercises, joint and tissue mobilization techniques, with accessory joint mobilization and neurodynamics performed by experienced physiotherapists. In order to treat radio-induced and drug-induced neuropathic pain, both aerobic and strengthening exercises are supervised by an experienced physiotherapist and carried out twice weekly for a total of 150 minutes of exercise. Finally, the treatment suggested to deal with chronic pain uses a multidisciplinary approach, including pain education interventions, pharmacological interventions, psychological interventions, and physiotherapy interventions.

To conclude. the classification of different types of shoulder pain following mammary carcinoma treatments requires specific and targeted physiotherapy interventions in which active therapeutic exercise has a central role.

Received 11/09/2019

Review began 11/13/2019 Review ended 12/15/2019 Published 12/18/2019

๑) Copyright 2019 Giacalone et al. This is an open access article distributed under the terms of the Creative Commons Attribution License CC-BY 3.0., which permits unrestricted use, distribution, and reproduction in any medium, provided the original author and source are credited.
Categories: Physical Medicine \& Rehabilitation, Oncology

Keywords: upper extremity pain, physical therapy, breast cancer, shoulder

\section{Introduction And Background}

Breast cancer is the most common malignancy in women and the main cause of morbidity and mortality. In fact, there are 1.67 million new cases of breast cancer in the world each year and 458,000 annual deaths related to it [1]. About $89 \%$ of women with breast cancer survive at least five years after treatment, but side effects may persist for months or years following surgery [2]. Pain and joint dysfunction of the upper limb are defined as the most frequent side effects by calculating a range of prevalence that varies between $12 \%$ and $51 \%$ for pain and between $1.5 \%$ and $50 \%$ for joint dysfunction [3-4].

In the study, there is a greater risk of shoulder pain presenting following treatments for mammary carcinoma in patients with a lower value on the Karnofsky Performance Status scale and a higher score on the Social Communication Questionnaire [5]. Furthermore, the patient's poor general physical condition, low socioeconomic status, non-Caucasian race, and, finally, a low score on the Quality of Life scale increase this probability. The meta-analysis study indicates that the predictors of pain are the presence of preoperative shoulder pain and the younger age of patients [6]. A high percentage of patients experiencing moderate pain have undergone mastectomy and extensive axillary dissection and present a greater number of removed lymph nodes, positive lymph nodes, and drains inserted during surgery. There is a likelihood of greater complications in patients complaining of moderate pain in the sub-acute period following surgery.

In many situations, together with the preoperative assessment, patients are given an educational booklet with a summary of the advice and precautions to be implemented in the period following the surgical operation, so as to have a reinforcement role on the information obtained during the preoperative meeting [7-8]. McNeely's study, in particular, suggests that a supervised rehabilitation intervention is preferable to the standard one, which instead uses an informative booklet, a written educational package, or unstructured or non-individualized exercises [8]. In fact, personalized physiotherapy demonstrates the ability to reduce 
complex problems related to the postsurgical morbidity of mammary carcinoma thanks to the early identification of symptoms. It is, therefore, essential to recognize the most effective treatment based on the pain presented by the patient. Shoulder pain following treatment for mammary carcinoma can, in fact, be divided into musculoskeletal nociceptive type pain, drug-induced neuropathic and radio induced types and, finally, as chronic persistent pain [9-10].

Musculoskeletal nociceptive pain arises from the fact that treatments for breast cancer directly involve the neuromusculoskeletal tissues of one or more limb areas, causing shoulder pain, joint limitation, and hyposthenia [11-12]. The population of breast cancer operated patients may present a reduced variety of motor strategy, producing movements with increasingly reduced ranges reporting a subacromial impingement and, therefore, pain [3,11,13-18]. In Ebaugh's study, it is stated that postural pain, scar formation, and protection posture cause a shortening of the small pectoral and large pectoral muscles [12]. It can cause a posture characterized by the depression and antepositioning of the shoulder. Radiation therapy and the subsequent tissue fibrosis can also exacerbate this misalignment, which would result in an incorrect relationship both between the scapula and the chest wall and between the humeral head and the glenoid fossa. These structural changes can become chronic in the musculoskeletal tissues related to the shoulder, eventually causing pain.

Neuropathic pain syndromes can be divided into neuropathic pain related to cancer, neuropathic pain caused by drug-induced treatment, and neuropathic pain associated with cancer [9]. Postmastectomy pain syndrome is a common example of neuropathic pain induced by cancer therapy. Radiotherapy can also cause neuropathic pain: in fact, it can affect the surrounding structures, including the nerves and the neural plexus [10]. Finally, neuropathic pain can be drug-induced by taking aromatase inhibitor drugs. They are the most frequently used hormonal treatment for the treatment of hormone-responsive tumors, which boasts the greatest scientific evidence [19].

However, about $50 \%$ of patients taking anti-aromatases report widespread musculoskeletal pain, defined as "aromatase inhibitor musculoskeletal syndrome," which persists even after stopping the drug. It is manifested by arthralgia, osteoporosis, and the risk of fractures. The onset of arthromial pain is reported as the most frequent cause of treatment suspension [20-21]. Lipps's study analyzes the data for radiotherapy side effects [22]. Although radiotherapy is an effective treatment for mammary carcinoma, some patients may report comorbidity in the ipsilateral shoulder. Fatigue, skin reactions, and pain are the most frequently reported side effects; in particular, over $60 \%$ of patients experience pain at the end of treatment and, in $4 \%$ of cases, pain is reported to be severe or very severe. Radiation therapy of muscles and connective tissues within the shoulder joint can lead to the formation of fibrosis and atrophy and, therefore, to pain.

Finally, chronic pain occurs in a proportion of up to $50 \%$ of patients six months after surgery [23]. Breast cancer survivors with persistent breast pain have significantly high levels of depressive symptoms, increased apprehension of pain, and increased anxiety as compared to patients who do not have persistent breast pain or women who have no history of cancer [24]. Inadequately managed postoperative pain is a relevant risk factor in chronic pain syndrome. Despite an $83 \%$ survival rate, it is estimated that between $25 \%$ and $60 \%$ of breast cancer survivors experience post-surgical persistent pain, associated with reduced quality of life and motor dysfunction [9]. Some patients with chronic pain show features that suggest central pain sensitization, a process characterized by a generalized hypersensitivity of the somatosensory system, defined as an amplification of the neural signal at the level of the central nervous system [25].

\section{Objectives}

The purpose of this research is to select articles related to physiotherapy interventions in relation to the topic of shoulder pain in women treated for breast cancer and to identify the most effective physiotherapy interventions according to evidence-based medicine (EBM) based on the classification of the different types of pain typically described as a result of treatments for mammary carcinoma.

\section{Review \\ Methods}

Research Question

What are the physiotherapy interventions with the most efficacy for the treatment of shoulder pain in women treated for mammary carcinoma?

\section{Eligibility Criteria}

*P (population): Patients treated for mammary carcinoma with shoulder pain. Treatments include surgical procedures, such as mastectomy, axillary lymph node dissection, sentinel lymph node biopsy, and taking anti-aromatase drugs and radiotherapy.

*I (intervention): Physiotherapeutic interventions recognized by scientific evidence useful for the reduction 


\section{Cureus}

of pain presented by patients following treatments for mammary carcinoma.

${ }^{*} \mathrm{C}$ (comparison): Patients who receive only standard assistance/usual care. In many studies, it is represented by preoperative counseling followed by the delivery of informative booklets.

*O (results): Definition of rehabilitative intervention demonstrating efficacy based on the classification of shoulder pain presented by patients following treatments for mammary carcinoma.

The linguistic restriction was chosen because all the studies were in English and the temporal restriction of the studies was of the last 10 years (2009-2019) in which it was possible to read the abstract and then the full text.

The articles obtained were selected on the basis of correlation criteria with themes concerning shoulder pain following mammary carcinoma and physiotherapy performed to treat this pain.

Sources of Information and Research

The search for relevant publications of the last 15 years (2004-2019) was carried out through the use of the PubMed, Medline, CINAHL, and Cochrane databases. In particular, on PubMed, Medline, and CINAHL, the research was conducted using the following Boolean operators:

(((("Upper Extremity"[Mesh] OR upper Extremit* AND pain OR Upper Limb* AND pain))) OR ("Shoulder Pain"[Mesh] OR shoulder pain*)) AND ((("Breast Neoplasms"[Mesh] OR ((Breast OR (Cancer OR Neoplasm* OR malignanc* OR tumor* OR tumour*)))) AND ("Shoulder"[Mesh] OR shoulder*))) AND ("Physical Therapy Modalities"[Mesh] OR Physical Therapy Modalit* OR Physical Therapy Techniqu* OR Physiotherap*)

In the Cochrane Library, a mesh search was performed with the following free words:

breast cancer or breast neoplasm or breast carcinoma or breast tumor and physiotherapy or physical therapy or physiotherapist or physical therapist and shoulder pain

Study Selection

The total number of articles identified through mesh research is 682 studies. Two-hundred ninety-nine articles were excluded because they did not meet the inclusion criteria, 258 articles were excluded after reading the abstract, and a further 112 after reading the full article text. Thirteen articles were found to be useful and relevant to the research question, in particular, four

systematic reviews, three narrative reviews, three randomized controlled trials, two randomized controlled pilot studies and one uncontrolled trial (Table 1).

\begin{tabular}{|c|c|c|c|}
\hline IDENTIFICATION & SCREENING & ELIGIBILITY & INCLUDED \\
\hline \multirow[t]{2}{*}{$\begin{array}{l}\text { Articles identified through the research: } \\
\text { Pubmed, Medline, Cinahl and Cochrane } \\
(\mathrm{N}=682)\end{array}$} & $\begin{array}{l}\text { Inclusion criteria: studies of the last } 10 \text { years, } \\
\text { English language, possible reading of the abstract } \\
(\mathrm{N}=283)\end{array}$ & $\begin{array}{l}\text { Abstract assessed } \\
\text { for eligibility } \\
(\mathrm{N}=125)\end{array}$ & $\begin{array}{l}\text { Full-text studies included } \\
\text { in qualitative summary } \\
(\mathrm{N}=13)\end{array}$ \\
\hline & Excluded studies $(\mathrm{N}=299)$ & $\begin{array}{l}\text { Excluded studies } \\
(\mathrm{N}=258)\end{array}$ & Excluded studies $(\mathrm{N}=112)$ \\
\hline
\end{tabular}

TABLE 1: Literature search of evidence-based physical therapy interventions in breast cancer patients with shoulder pain

Shoulder pain was then classified as musculoskeletal nociceptive pain, drug-induced and radioinduced neuropathic pain, and chronic pain. Based on the type of pain, the recommended physiotherapy treatment is identified according to EBM.

Risk of Bias Across Studies

The possibility of bias for structural variability of the studies considered and for the subjective evaluation of the inclusion of the studies following their full-text reading. Furthermore, the nature of the treatments made it impossible to carry out a blind study both for patients and for the health care professionals who apply them. Finally, the three narrative reviews cannot be evaluated according to this scheme.

\section{Results}


The data of the recent literature suggest that multifactorial physiotherapy (e.g. stretching and exercises) and active exercises are effective for the treatment of postoperative pain and reduced joint following surgery for mammary carcinoma [4]. High-quality studies state that carefully monitored exercise prescriptions and analysis of persistent upper limb dysfunctions are necessary $[8,26]$. In fact, perspective surveillance and target physiotherapy, as compared to education, show that target physiotherapy is more suitable for women with mammary carcinoma due to the early identification of upper limb morbidity. In Rafn's study, in fact, the patients treated for mammary carcinoma are divided into two groups with randomized modality: one group is followed with prospective surveillance and target physiotherapy and one group is followed with standard care, consisting of preoperative education and the delivery of a booklet of exercises to be performed at home [7]. Perspective surveillance consists of the quarterly monitoring of the patients, assessing the shoulder articulation variables, strength, volume, and functionality of the upper limb. If problems are identified to the upper limb, the patients are sent to perform physiotherapy, which, in this way, becomes the "target." At 12 months, patients treated with education alone presented more complex morbidity than the group treated with target physiotherapy. In the postoperative period, it is important to consider the early implementation of the exercise, although this approach should be cautious to avoid complications at drainage points [8]. For the treatment of musculoskeletal nociceptive pain, the use of manual therapy and complex decongestive physiotherapy in elderly patients operated on for mammary carcinoma was evaluated as effective. The use of manual therapy can, indeed, improve the feeling of pain and increase the range of motion (ROM) of the shoulder [27]. In the same way, the use of myofascial inductions can be moderately effective [28]. However, the most solid positive effects are identified in therapeutic exercise for the reduction of the pain and in yoga with effects on the state of anxiety [29]. Active exercises show that the best results of joint recovery are achieved between the 28 th and 42 nd postoperative days [4]. In the sub-acute phase, the muscle groups that need major reinforcement are those of the rotator cuff but also the serratus anterior, upper and middle trapezius, the rhomboids, the biceps femoris, and the small and large pectoralis [14]. Training can start with exercises that use elastic bands, always taking great care of maintaining the correct posture. It is recommended to carry out 10 to 15 repetitions for each exercise for two sets, twice a week. The best way to start is to begin with more repetitions and less resistance and gradually increase resistance by reducing repetitions. Later, we will move to using machinery to increase reinforcement [30]. In addition to selective reinforcement exercises, control exercises and neuromuscular proprioceptive facilitation are recommended for the restoration of the correct scapulohumeral rhythm [8,31]. The most effective treatment with regard to neuropathic pain given by taking aromatase inhibitors is found in the 12-month extended exercise, which led to an improvement in arthralgia in previously inactive mammary carcinoma survivors compared with patients who received standard informational treatment [21]. The treatment proposed in Irwin's study foresees the execution of exercises of both aerobic and reinforcement types, performed with supervision and carried out twice weekly for a total of 150 minutes [21]. It should also be noted that, although some benefits were found after three months of exercise, the most obvious improvements occurred after 12 months, reporting a follow-up with a reduction in pain of $29 \%$. For the treatment of arthralgia associated with anti-aromatase drugs, the efficacy of the neurotaping used for five weeks was also observed. The result obtained was the subjective reduction of pain [19]. Regarding the neuropathic pain given by radiotherapy, the treatment was evaluated by means of a moderate intensity, supervised therapeutic exercise. In addition to improving the sensation of pain, statistically significant improvements were calculated in the World Health Organization Quality of Life (WHOQOL), brief fatigue inventory (BFI), and shoulder ROM [32]. The studies of Nijs and Geneen provide a general overview regarding a greater understanding of the psychosocial mechanisms of chronic pain in patients treated for breast cancer and deepen on how to set up exercise with patients having different side effects [10,33]. Lack of sleep induces a low-grade inflammatory response that can lead to pain sensitization typical of chronic pain. Pain education is an effective strategy for treating chronic cancer-related pain with few side effects. Similarly, cognitivebehavioral therapy for sleep problems, stress management, and active exercise can improve sleep in these patients. The rehabilitative approach which includes sleep management, functional targets, and graded therapeutic exercise with selective muscle strengthening, are often associated together with psychological strategies for the management of pain, anxiety, and depression. Physiotherapeutic activity, therefore, aims to assist the psychologist in the active management of pain through the positive experience of guided exercise and muscle activation, also associated with the production of oxytocin. The physical exercise associated with pain education and cognitive-behavioral therapy is, therefore, effective for the reduction of persistent pain. Indeed, there are favorable effects of therapeutic exercise on the reduction of chronic pain and an increased physical function, although the effects are mild to moderate. Finally, variable effects for psychological functions and quality of life have been calculated. See Tables 2-3. 


\section{Cureus}

\begin{tabular}{|c|c|c|c|c|c|c|c|c|c|c|c|c|c|}
\hline Article & 1 & 2 & 3 & 4 & 5 & 6 & 7 & 8 & 9 & 10 & 11 & 12 & Score \\
\hline De Groef A, et al. & $\mathrm{Y}$ & $\mathrm{Y}$ & $\mathrm{N}$ & $\mathrm{N}$ & $\mathrm{Y}$ & $\mathrm{Y}$ & U & $\mathrm{Y}$ & $\mathrm{Y}$ & $\mathrm{Y}$ & $\mathrm{Y}$ & $\mathrm{N}$ & $8 / 12$ \\
\hline Rafn BS, Hung, et al. & $\mathrm{Y}$ & $\mathrm{Y}$ & $\mathrm{N}$ & $\mathrm{N}$ & $\mathrm{Y}$ & $\mathrm{Y}$ & $\mathrm{Y}$ & $\mathrm{Y}$ & $\mathrm{Y}$ & $\mathrm{Y}$ & $\mathrm{Y}$ & $\mathrm{Y}$ & 10/12 \\
\hline McNeely, Campbell, et al. & $\mathrm{N}$ & $\mathrm{N}$ & $\mathrm{N}$ & $\mathrm{N}$ & $\mathrm{Y}$ & $\mathrm{Y}$ & $\mathrm{Y}$ & $\mathrm{Y}$ & $\mathrm{Y}$ & U & $\mathrm{Y}$ & $\mathrm{Y}$ & 7/12 \\
\hline Conejo I, Pajares, et al. & $\mathrm{Y}$ & $\mathrm{Y}$ & $\mathrm{N}$ & $\mathrm{N}$ & $\mathrm{N}$ & $\mathrm{Y}$ & $\mathrm{Y}$ & $\mathrm{Y}$ & $\mathrm{Y}$ & $\mathrm{Y}$ & $\mathrm{Y}$ & $\mathrm{Y}$ & $9 / 12$ \\
\hline Irwin ML, Cartmel B, et al. & $\mathrm{Y}$ & $\mathrm{Y}$ & $\mathrm{N}$ & $\mathrm{N}$ & $\mathbf{N}$ & $\mathrm{Y}$ & $\mathrm{Y}$ & $\mathrm{Y}$ & $\mathrm{Y}$ & U & $\mathrm{Y}$ & $\mathrm{Y}$ & $8 / 12$ \\
\hline Tunay VB, Akbayrak, et al. & $\mathrm{N}$ & $\mathrm{Y}$ & $\mathrm{N}$ & $\mathrm{N}$ & $\mathrm{Y}$ & $\mathrm{Y}$ & $\mathrm{Y}$ & $\mathrm{Y}$ & $\mathrm{Y}$ & $\mathrm{Y}$ & $\mathrm{Y}$ & $\mathrm{Y}$ & 9/12 \\
\hline Castro-Martin E, et al. & $\mathrm{Y}$ & $\mathrm{U}$ & $\mathrm{N}$ & U & $\mathrm{Y}$ & $\mathrm{Y}$ & $\mathrm{Y}$ & $\mathrm{Y}$ & Y & $\mathrm{Y}$ & $\mathrm{Y}$ & $\mathrm{Y}$ & 9/12 \\
\hline Olsson Möller U, Beck I, et al. & $\mathrm{N}$ & U & U & U & U & $\mathrm{Y}$ & $\mathrm{Y}$ & $\mathrm{Y}$ & $\mathrm{Y}$ & U & $\mathrm{Y}$ & $\mathrm{Y}$ & $6 / 12$ \\
\hline Hwang JH, Chang HJ, et al. & $\mathrm{Y}$ & $\mathrm{N}$ & $\mathrm{N}$ & $\mathrm{N}$ & U & $\mathrm{Y}$ & $\mathrm{Y}$ & $\mathrm{Y}$ & U & U & $\mathrm{Y}$ & $\mathrm{Y}$ & $6 / 12$ \\
\hline Geneen LJ, Moore RA, et al. & $\mathrm{Y}$ & $\mathrm{Y}$ & $\mathrm{N}$ & $\mathrm{N}$ & $\mathrm{Y}$ & $\mathrm{Y}$ & $\mathrm{Y}$ & $\mathrm{Y}$ & $\mathrm{N}$ & $\mathrm{U}$ & $\mathrm{Y}$ & $\mathrm{N}$ & $7 / 12$ \\
\hline
\end{tabular}

\section{TABLE 2: Risk-of-bias assessment using the Cochrane tool}

Criteria Items: 1, Was the method of randomization adequate? 2, Was the treatment allocation concealed? 3, Was the patient blinded to the intervention? 4, Was the care provider blinded to the intervention? 5, Was the outcome assessor blinded to the intervention? 6, Was the dropout rate described and acceptable? 7, Were all randomized participants analyzed in the group to which they were allocated? 8 , Are reports of the study free of suggestion of selective outcome reporting? 9, Were the groups similar at baseline regarding the most important prognostic indicators? 10 , Were co-interventions avoided or similar? 11, Was the compliance acceptable in all groups? 12, Was the timing of the outcome assessment similar in all groups?

$\mathrm{N}$, no; U, unsure; $\mathrm{Y}$, yes

\begin{tabular}{|c|c|c|c|c|c|}
\hline AUTHOR & YEAR & OBJECTIVE & SAMPLE & MEANS & RESULTS \\
\hline $\begin{array}{l}\text { De Groef } \\
\text { A, Van } \\
\text { Kampen } \\
\text { M, } \\
\text { Dieltjens } \\
\text { E et al. }\end{array}$ & 2015 & $\begin{array}{l}\text { Systematic review to } \\
\text { evaluate the effectiveness } \\
\text { of various physiotherapy } \\
\text { modalities and their } \\
\text { timing for the recovery of } \\
\text { articularity in the upper } \\
\text { limb and pain } \\
\text { management following } \\
\text { treatment for mammary } \\
\text { carcinoma. Modalities } \\
\text { include passive } \\
\text { mobilization, passive } \\
\text { stretching, myofascial } \\
\text { techniques and active } \\
\text { exercise }\end{array}$ & $18 \mathrm{RCT}$ & & $\begin{array}{l}\text { Multi-factor physiotherapy (e.g. stretching and } \\
\text { exercises) and active exercises have proven to } \\
\text { be effective for the treatment of postoperative } \\
\text { pain and reduced articulation following surgery } \\
\text { for mammary carcinoma }\end{array}$ \\
\hline \multirow[t]{2}{*}{$\begin{array}{l}\text { Geneen } \\
\text { LJ, } \\
\text { Moore } \\
\text { RA et al. }\end{array}$} & \multirow[t]{2}{*}{2017} & $\begin{array}{l}\text { Cochrane Systematic } \\
\text { Review to determine the } \\
\text { effectiveness of different } \\
\text { activities and therapeutic } \\
\text { exercises for the } \\
\text { reduction of chronic pain } \\
\text { and its impact on } \\
\text { function, quality of life } \\
\text { and to verify the evidence } \\
\text { for any side effect } \\
\text { associated with physical } \\
\text { activity and therapeutic } \\
\text { intervention. }\end{array}$ & $\begin{array}{l}21 \text { reviews } \\
\text { with } 381 \\
\text { studies. Of } \\
\text { these, } 264 \\
\text { studies were } \\
\text { used for } \\
\text { qualitative } \\
\text { analysis. }\end{array}$ & AMSTAR & $\begin{array}{l}\text { There are some favorable effects of therapeutic } \\
\text { exercise on pain relief and increased physical } \\
\text { function, although these effects are mild to } \\
\text { moderate. There are variable effects for } \\
\text { psychological functions and quality of life. } \\
\text { Physical activity and therapeutic exercise are } \\
\text { interventions with few side effects. }\end{array}$ \\
\hline & & $\begin{array}{l}\text { Cochrane systematic } \\
\text { reviews of RCTs to } \\
\text { evaluate the efficacy and }\end{array}$ & & & $\begin{array}{l}\text { Exercises can bring significant clinical } \\
\text { improvement in shoulder joint in women with } \\
\text { mammary carcinoma. In the postoperative }\end{array}$ \\
\hline
\end{tabular}




\section{Cureus}

\begin{tabular}{|c|c|c|c|c|c|}
\hline $\begin{array}{l}\text { McNeely } \\
\text { M. L., } \\
\text { Campbell } \\
\text { et al. }\end{array}$ & 2010 & $\begin{array}{l}\text { safety of therapeutic } \\
\text { exercise for the } \\
\text { prevention or } \\
\text { improvement of upper } \\
\text { limb dysfunctions due to } \\
\text { treatment for mammary } \\
\text { carcinoma. }\end{array}$ & 10 of $24 \mathrm{RCTs}$ & & $\begin{array}{l}\text { period, it is important to consider the early } \\
\text { implementation of the exercise, although this } \\
\text { approach should be cautious to avoid } \\
\text { complications at drainage points. High-quality } \\
\text { studies state that carefully monitored exercise } \\
\text { prescriptions and analysis of persistent upper } \\
\text { limb dysfunctions are necessary. }\end{array}$ \\
\hline $\begin{array}{l}\text { Amatya } \\
\text { B., Khan } \\
\text { et al. }\end{array}$ & 2017 & $\begin{array}{l}\text { Review to optimize post- } \\
\text { acute care in } \\
\text { rehabilitative mammary } \\
\text { carcinoma survivors }\end{array}$ & $\begin{array}{l}\text { Narrative } \\
\text { review }\end{array}$ & & $\begin{array}{l}\text { The rehabilitation intervention should be } \\
\text { considered early in order to maintain functional } \\
\text { capacity and to reduce the risk of losing } \\
\text { important skills or independence and should be } \\
\text { individualized according to the stage of illness, } \\
\text { functional deficits, personal requests, and } \\
\text { specific objectives. Multidisciplinary } \\
\text { rehabilitation and uni-disciplinary interventions, } \\
\text { such as physiotherapy, have been shown to be } \\
\text { useful in reducing disability and improving } \\
\text { participation and quality of life. }\end{array}$ \\
\hline $\begin{array}{l}\text { Tunay V. } \\
\text { B., } \\
\text { Akbayrak } \\
\text { et al. }\end{array}$ & 2012 & $\begin{array}{l}\text { Evaluate the effects of } \\
\text { manual therapy and } \\
\text { therapeutic exercise on } \\
\text { shoulder function, pain, } \\
\text { and lymphedema in } \\
\text { elderly patients with } \\
\text { mammary carcinoma }\end{array}$ & $\begin{array}{l}40 \text { women } \\
\text { with radical } \\
\text { mastectomy }\end{array}$ & $\begin{array}{l}\text { goniometer, VAS, metro, } \\
\text { DASH, SF-36, }\end{array}$ & $\begin{array}{l}\text { The study demonstrates the effectiveness of } \\
\text { manual therapy and complex decongestive } \\
\text { physiotherapy in elderly patients operated for } \\
\text { mammary carcinoma. The use of manual } \\
\text { therapy can reduce pain and improve shoulder } \\
\text { ROM. }\end{array}$ \\
\hline $\begin{array}{l}\text { Irwin, M. } \\
\text { L., } \\
\text { Cartmel, } \\
\text { B et al. }\end{array}$ & 2015 & $\begin{array}{l}\text { Randomized exercise trial } \\
\text { to calculate the impact of } \\
\text { therapeutic exercise } \\
\text { versus standard } \\
\text { treatment in women with } \\
\text { anti-aromatase-induced } \\
\text { arthralgia }\end{array}$ & $\begin{array}{l}121 \text { women } \\
\text { surviving } \\
\text { mammary } \\
\text { carcinoma } \\
\text { with Al } \\
\text { arthralgia, of } \\
\text { which } 61 \\
\text { treated with } \\
\text { exercises of } \\
\text { increasing } \\
\text { intensity }\end{array}$ & $\begin{array}{l}\text { Brief Pain Inventory (BPI), } \\
\text { Western Ontario and } \\
\text { McMaster Universities } \\
\text { Osteoarthritis (WOMAC) } \\
\text { index, Disabilities of the Arm, } \\
\text { Shoulder, and Hand (DASH) } \\
\text { questionnaire, dynamometer. }\end{array}$ & $\begin{array}{l}\text { Exercise maintained for } 12 \text { months led to an } \\
\text { improvement in arthralgia in previously inactive } \\
\text { mammary carcinoma survivors. }\end{array}$ \\
\hline $\begin{array}{l}\text { Conejo I., } \\
\text { Pajares } \\
\text { et al. }\end{array}$ & 2018 & $\begin{array}{l}\text { Pilot RCT study to } \\
\text { evaluate the efficacy of } \\
\text { neurotaping in the } \\
\text { treatment of arthralgia } \\
\text { associated with anti- } \\
\text { aromatases in women } \\
\text { treated for mammary } \\
\text { carcinoma }\end{array}$ & $\begin{array}{l}40 \text { women } \\
\text { with } \\
\text { endocrine } \\
\text { therapy after } \\
\text { mammary } \\
\text { carcinoma }\end{array}$ & $\begin{array}{l}\text { profile of mood state } \\
\text { (POMS), fatigue evaluation } \\
\text { (Quickpiper), quality of life } \\
\text { (EORTC QLQ-C30), } \\
\text { dynamometer, VAS, Spine } \\
\text { Functional Index (SFI), Upper } \\
\text { Limb Functional Index (ULFI), } \\
\text { Backache Disability Index } \\
\text { (BADIX) }\end{array}$ & $\begin{array}{l}\text { After } 5 \text { weeks of neuromuscular taping, patients } \\
\text { treated with neuromuscular taping have } \\
\text { improved their pre-existing musculoskeletal } \\
\text { symptoms, particularly in the subjective } \\
\text { sensation of pain. }\end{array}$ \\
\hline $\begin{array}{l}\text { Casla S., } \\
\text { Hojman } \\
\text { et al. }\end{array}$ & 2015 & $\begin{array}{l}\text { Provide a general } \\
\text { overview of the benefits } \\
\text { of therapeutic exercise } \\
\text { on breast cancer patients } \\
\text { and on recommendations } \\
\text { for setting exercise with } \\
\text { patients having different } \\
\text { side effects }\end{array}$ & $\begin{array}{l}\text { Narrative } \\
\text { review }\end{array}$ & & $\begin{array}{l}\text { Exercise is a global intervention that improves } \\
\text { the physical, psychological and psychosocial } \\
\text { aspects of patients with mammary carcinoma. } \\
\text { Appropriate exercises can, in fact, reduce the } \\
\text { side effects and other comorbidities that } \\
\text { patients can present in the long term, thus } \\
\text { improving the quality of life and their survival. }\end{array}$ \\
\hline $\begin{array}{l}\text { Nijs J., } \\
\text { Leysen } \\
\text { et al. }\end{array}$ & 2018 & $\begin{array}{l}\text { Trying to explain how } \\
\text { increased knowledge in } \\
\text { neuroscience can } \\
\text { improve adult } \\
\text { rehabilitation following } \\
\text { cancer treatment within }\end{array}$ & $\begin{array}{l}\text { Narrative } \\
\text { review }\end{array}$ & & $\begin{array}{l}\text { Pain education is an effective strategy for } \\
\text { treating cancer-related pain. Furthermore, the } \\
\text { neuro-immunological knowledge of how stress } \\
\text { affects pain emphasizes the importance of } \\
\text { integrating stress management within the } \\
\text { rehabilitation approach. Lack of sleep induces a } \\
\text { low-grade inflammatory response that can lead } \\
\text { to pain sensitization typical of chronic pain. } \\
\text { Cognitive behavioral therapy for sleep }\end{array}$ \\
\hline
\end{tabular}




\section{Cureus}

\begin{tabular}{|c|c|c|c|c|c|}
\hline & & $\begin{array}{l}\text { an evidence-based } \\
\text { perspective }\end{array}$ & & & $\begin{array}{l}\text { problems, stress management, and active } \\
\text { exercise can improve sleep in these patients. } \\
\text { Exercise is effective for pain relief following } \\
\text { cancer and can reduce the pain associated with } \\
\text { hormonal cancer treatments. }\end{array}$ \\
\hline $\begin{array}{l}\text { Rafn B. } \\
\text { S., Hung } \\
\text { et al. }\end{array}$ & 2018 & $\begin{array}{l}\text { Randomized controlled } \\
\text { single-blind pilot studies } \\
\text { to assess prospective } \\
\text { surveillance and target } \\
\text { physiotherapy compared } \\
\text { to education on the } \\
\text { prevalence of arm } \\
\text { morbidity following } \\
\text { mammary carcinoma } \\
\text { surgery }\end{array}$ & $\begin{array}{l}41 \text { women } \\
\text { operated for } \\
\text { mammary } \\
\text { carcinoma, of } \\
\text { which } 21 \\
\text { followed } \\
\text { target } \\
\text { physiotherapy } \\
\text { and } 20 \text { with } \\
\text { education }\end{array}$ & $\begin{array}{l}\text { Hand-held dynamometer } \\
\text { (HHD; MicroFET2 Hand Held } \\
\text { Dynamometer; Hoggan } \\
\text { Scientific, Salt Lake City, } \\
\text { USA) and HHD hand-held } \\
\text { dynamometer (Jamar Plus + } \\
\text { Digital Hand Dynamometer; } \\
\text { Lafayette Instrument, } \\
\text { Lafayette, IN, USA) } \\
\text { Wuppertal, Germany), Upper } \\
\text { Extremity Functional Index, } \\
\text { QuickDASH, Functional } \\
\text { Assessment of Chronic } \\
\text { Illness Therapy (FACIT) - } \\
\text { Breast (FACT-B + 4) }\end{array}$ & $\begin{array}{l}\text { At } 12 \text { months, patients treated with education } \\
\text { alone presented more complex morbidity than } \\
\text { the group treated with target physiotherapy. } \\
\text { Target physiotherapy is therefore suitable for } \\
\text { women with mammary carcinoma due to the } \\
\text { early identification of upper limb morbidity }\end{array}$ \\
\hline $\begin{array}{l}\text { U. } \\
\text { Olsson } \\
\text { Möller I. } \\
\text { Beck et } \\
\text { al. }\end{array}$ & 2019 & $\begin{array}{l}\text { Systematic review of } \\
\text { systematic reviews to } \\
\text { assess current evidence } \\
\text { on rehabilitation in female } \\
\text { patients following } \\
\text { treatments for mammary } \\
\text { carcinoma }\end{array}$ & $\begin{array}{l}37 \text { systematic } \\
\text { reviews of } \\
1269 \text { studies }\end{array}$ & & $\begin{array}{l}\text { There are strong positive effects in therapeutic } \\
\text { exercise and in yoga for women treated for } \\
\text { mammary carcinoma. Interventions with } \\
\text { physical exercise improve shoulder joint } \\
\text { movement, pain, lymphedema, fatigue and } \\
\text { quality of life. Yoga instead influences the state } \\
\text { of anxiety, depression, sleep disorders, } \\
\text { gastrointestinal symptoms and quality of life. }\end{array}$ \\
\hline $\begin{array}{l}\text { Eduardo } \\
\text { Castro- } \\
\text { Martin, } \\
\text { Lucia } \\
\text { Ortiz- } \\
\text { Comino } \\
\text { et al. }\end{array}$ & 2016 & $\begin{array}{l}\text { Investigate the immediate } \\
\text { effect of myofascial } \\
\text { induction related to } \\
\text { electrotherapy as a } \\
\text { control treatment on } \\
\text { perceived pain, cervical- } \\
\text { shoulder ROM and mood } \\
\text { of patients who survived } \\
\text { mammary carcinoma. It } \\
\text { also examines the } \\
\text { relationship between pain } \\
\text { changes and the cervical } \\
\text { and ipsilateral shoulder } \\
\text { ROM to the mammary } \\
\text { carcinoma. }\end{array}$ & $\begin{array}{l}\text { Randomized } \\
\text { single-blind } \\
\text { study and } \\
\text { placebo } \\
\text { control. } 21 \\
\text { cases } \\
\text { diagnosed } \\
\text { with } \\
\text { mammary } \\
\text { carcinoma } \\
\text { stage I-IIIA } \\
\text { and have } \\
\text { completed } \\
\text { adjuvant } \\
\text { therapy } \\
\text { (excluding } \\
\text { hormone } \\
\text { therapy) }\end{array}$ & $\begin{array}{l}\text { VAS, goniometer, the Profile } \\
\text { of Mood States and the } \\
\text { Attitudes Towards Massage } \\
\text { Scale. }\end{array}$ & $\begin{array}{l}\text { A single session of myofascial induction } \\
\text { reduces the intensity of pain and improves } \\
\text { cervical-shoulder ROM significantly compared } \\
\text { to the placebo group. }\end{array}$ \\
\hline $\begin{array}{l}\text { Hwang } \\
\text { JH, } \\
\text { Chang } \\
\text { HJ, Shim } \\
\text { YH, et al. }\end{array}$ & 2008 & $\begin{array}{l}\text { Examine whether } \\
\text { moderate-intensity } \\
\text { supervised exercise can } \\
\text { mitigate radiotherapy } \\
\text { related complications }\end{array}$ & $\begin{array}{l}\text { RCTs on } 37 \\
\text { women } \\
\text { treated with } \\
\text { radiotherapy, } \\
\text { of which } 17 \\
\text { were in the } \\
\text { supervised } \\
\text { exercise } \\
\text { group and } 20 \\
\text { in the control } \\
\text { group with } \\
\text { exercises to } \\
\text { perform at } \\
\text { home }\end{array}$ & $\begin{array}{l}\text { World Health Organization } \\
\text { Quality of Life-BREF } \\
\text { (WHOQOL-BREF), brief } \\
\text { fatigue inventory (BFI), } \\
\text { shoulder ROM and VAS }\end{array}$ & $\begin{array}{l}\text { Statistically significant differences were found in } \\
\text { changes in the WHOQOL, BFI, shoulder ROM, } \\
\text { and pain scales }\end{array}$ \\
\hline
\end{tabular}

\section{TABLE 3: Summary of studies that investigated the evidence-based physical therapy}


interventions in breast cancer patients with shoulder pain

$\mathrm{RCT}$ : randomized controlled trials; ROM: range of motion

\section{Discussion}

Summary of Evidence

The present article subdivides shoulder pain in breast cancer survivors into three categories: musculoskeletal pain, neuropathic pain, of which the topic of drug-induced and radio-induced pain was examined, and finally chronic and central sensitization pain.

Nociceptive musculoskeletal pain, defined as a physiological response to an algogenic stimulus, is due to peripheral neuronal activity resulting from potentially harmful tissue stimuli [34]. Studies suggest treating it through joint and tissue mobilization techniques and manual therapy techniques with accessory joint mobilization and neurodynamics [35-36].

Neuropathic pain results from damage to peripheral or central nervous tissue, which causes chronic and selfsustained nerve stimulation, which results in altered responses of the somatosensory neurons. It is a burning, paroxysmal, electric shock pain and can be associated with paraesthesia, allodynia, or hyperalgesia [37]. Neuropathic pain may appear following treatment with radiotherapy: asthenia, skin reactions, and pain are, in fact, the most frequently reported side effects from radiotherapy [38]. Irradiation of the muscles and connective tissues within the shoulder joint can also lead to the formation of fibrosis and atrophy. Neuropathic pain can also occur following the use of hormonal therapy with aromatase inhibitors. This pain occurs in about $50 \%$ of women who survived breast cancer [38] and is described as widespread musculoskeletal pain, also called "aromatase inhibitor musculoskeletal syndrome or AIMSS." This pain persists even after stopping the drug. The side effects of aromatase inhibitors are, in fact, mainly at the expense of the osteoskeletal system with arthromial pain, osteoporosis, and risk of fractures. To address and reduce radio-induced and drug-induced neuropathic pain, both aerobic and reinforcement exercises have been proposed with the supervision of a physiotherapist to be performed twice weekly for a total of 150 minutes of exercise [22].

Chronic pain is defined as a pain present for at least six months and associated with profound changes in the personality and lifestyle of the patient that constitute maintenance factors independent of the action of nociceptors [39]. An inadequately managed pain in the postoperative phase is a significant risk factor in chronic pain syndrome, which occurs at a percentage that reaches $50 \%$ of patients at six months after surgery, as opposed to $12.7 \%$ of women who have no history of breast cancer [40]. The treatment of chronic pain occurs through multidisciplinary management, including pain education interventions, pharmacological interventions, psychological interventions, and physiotherapy interventions [41].

\section{Limitations}

The present study contains several limitations. Among them, we include the scarce bibliography concerning the specific topic of shoulder pain following treatment for mammary carcinoma, although it is a very present theme on an epidemiological level. Further, only a few studies deal in depth with the methods of physiotherapy intervention carried out. Finally, the final selection of the articles chosen based on thematic correlation criterion was carried out by the same author, which compromises the objectivity of the study.

\section{Conclusions}

Following surgery for breast cancer, multifactor physiotherapy was effective in the treatment of nociceptive musculoskeletal pain. It provides for tissue, accessory and neurodynamic joint mobilization plus active exercises with increasing intensity. After the sub-acute period, selective reinforcement exercises and neuromuscular proprioceptive facilitation are recommended for the restoration of the correct scapulohumeral rhythm. For drug-induced neuropathic pain, active exercise maintained for 12 months led to an improvement in arthralgia in previously inactive patients. The efficacy of the neurotaping used for five weeks was also observed, obtaining the subjective reduction of pain given by arthralgia associated with the use of anti-aromatase drugs. The most effective treatment for radio-induced neuropathic pain is a supervised and moderate-intensity therapeutic exercise. In addition to improving the pain sensation, statistically significant improvements in the WHOQOL, BFI, and shoulder ROM scales were calculated. Finally, in patients with chronic pain, multidisciplinary rehabilitation is useful to reduce disability and improve quality of life. This intervention is structured by combining psychological support for pain management and education, techniques for improving sleep problems, and active therapeutic exercise.

\section{Additional Information}

\section{Disclosures}


Conflicts of interest: In compliance with the ICMJE uniform disclosure form, all authors declare the following: Payment/services info: All authors have declared that no financial support was received from any organization for the submitted work. Financial relationships: All authors have declared that they have no financial relationships at present or within the previous three years with any organizations that might have an interest in the submitted work. Other relationships: All authors have declared that there are no other relationships or activities that could appear to have influenced the submitted work.

\section{References}

1. International Agency for Research on Cancer. Globocan 2012: Estimated cancer incidence, mortality and prevalence worldwide in 2012. (2012). https://publications.iarc.fr/Databases/Iarc-Cancerbases/GLOBOCAN2012-Estimated-Cancer-Incidence-Mortality-And-Preval....

2. Sprod LK, Janelsins MC, Palesh OG, et al.: Health-related quality of life and biomarkers in breast cancer survivors participating in tai chi chuan. J Cancer Surviv. 2012, 6:146-154. 10.1007/s11764-011-0205-7

3. Rietman JS, Dijkstra PU, Hoekstra HJ, Eisma WH, Szabo BG, Groothoff JW, Geertzen JHB: Late morbidity after treatment of breast cancer in relation to daily activities and quality of life: a systematic review. Eur J Surg Oncol. 2003, 29(3):229-238. 10.1053/ejso.2002.1403

4. De Groef A, Van Kampen M, Dieltjens E, Christiaens MR, Neven P, Geraerts I, Devoogdt N: Effectiveness of postoperative physical therapy for upper-limb impairments after breast cancer treatment: a systematic review. Arch Phys Med Rehab. 2015, 6:2015-2013. 10.1016/j.apmr.2015.01.006

5. Miaskowski C, Paul SM, Cooper B, et al.: Identification of patient subgroups and risk factors for persistent arm/shoulder pain following breast cancer surgery. Eur J Oncol Nurs. 2014, 18:242-253.

10.1016/j.ejon.2013.12.002

6. Wang L, Guyatt GH, Kennedy SA, et al.: Predictors of persistent pain after breast cancer surgery: a systematic review and meta-analysis of observational studies. CMAJ. 2016, 188:E352-E361. 10.1503/cmaj.151276

7. Rafn BS, Hung S, Hoens AM, et al.: Prospective surveillance and targeted physiotherapy for arm morbidity after breast cancer surgery: a pilot randomized controlled trial. Clin Rehabil. 2018, 32:811-826. 10.1177/0269215518757292

8. McNeely ML, Campbell K, Ospina M, Rowe BH, Dabbs K, Klassen TP, Courneya K: Exercise interventions for upper-limb dysfunction due to breast cancer treatment. Cochrane Database Syst Rev. 2010, 2010:CD005211. 10.1002/14651858.CD005211.pub2

9. Nijs J, Torres- Cueco R, van Wilgen CP, et al.: Applying modern pain neuroscience in clinical practice: criteria for the classification of central sensitization pain. Pain Physician. 2014, 17:447-457.

10. Nijs J, Leysen L, Pas R, et al.: Treatment of pain following cancer: applying neuro-immunology in rehabilitation practice. Disabil Rehabil. 2018, 40:714-721. 10.1080/09638288.2016.1261418

11. Brookham RL, Cudlip AC, Dickerson CR: Examining upper limb kinematics and dysfunction of breast cancer survivors in functional dynamic tasks. Clin Biomech. 2018, 55:86-93. 10.1016/j.clinbiomech.2018.04.010

12. Ebaugh D, Spinelli B, Schmitz KH: Shoulder impairments and their association with symptomatic rotator cuff disease in breast cancer survivors. Med Hypotheses. 2011, 77:481-487. 10.1016/j.mehy.2011.06.015

13. Lee SB, Kim KJ, O’Driscoll SW, Morrey BF, An KN: Dynamic glenohumeral stability provided by the rotator cuff muscles in the mid-range and end-range of motion: a study in cadavera. J Bone Joint Surg. 2000, 82:849-857. 10.2106/00004623-200006000-00012

14. Shamley D, Lascurain-Aguirrebeña I, Oskrochi R: Clinical anatomy of the shoulder after treatment for breast cancer. Clin Anat. 2014, 27:467-477. 10.1002/ca.22267

15. Lee TS, Kilbreath SL, Refshauge KM, Herbert RD, Beith JM: Prognosis of the upper limb following surgery and radiation for breast cancer. Breast Cancer Res Treat. 2008, 110:19-37. 10.1007/s10549-007-9710-9

16. Devoogdt N, Van Kampen M, Christiaens MR, et al.: Short- and long-term recovery of upper limb function after axillary lymph node dissection. Eur J Cancer Care. 2011, 20:77-86. 10.1111/j.1365-2354.2009.01141.x

17. Thomas-Maclean RL, Hack T, Kwan W, Towers A, Miedema B, Tilley A.: Arm morbidity and disability after breast cancer: new directions for care. Oncol Nurs Forum. 2008, 35:65-71. 10.1188/08.ONF.65-71

18. Kaya T, Karatepe AG, Gunaydn R, Yetis H, Uslu A: Disability and health-related quality of life after breast cancer surgery: relation to impairments. South Med J. 2010, 103:37-41. 10.1097/SMJ.0b013e3181c38c41

19. Conejo I, Pajares B, Alba E, Cuesta-Vargas AI: Effect of neuromuscular taping on musculoskeletal disorders secondary to the use of aromatase inhibitors in breast cancer survivors: a pragmatic randomised clinical trial. BMC Complement Altern Med. 2018, 18:1-19. 10.1186/s12906-018-2236-3

20. Burton AW, Fanciullo GJ, Beasley RD, Fisch MJ: Chronic pain in the cancer survivor: a new frontier . Pain Med. 2007, 8:189-198. 10.1111/j.1526-4637.2006.00220.x

21. Irwin ML, Sachdev S, Strauss JB: Quantifying radiation dose delivered to individual shoulder muscles during breast radiotherapy. Radiother Oncol. 2017, 122.3:431-436. 10.1016/j.radonc.2016.12.032

22. Irwin ML, Cartmel B2, Gross CP, et al.: Randomized exercise trial of aromatase inhibitor-induced arthralgia in breast cancer survivors. J Clin Oncol. 2015, 33:1104-1111. 10.1200/JCO.2014.57.1547

23. Fayaz A, Croft P, Langford RM, Donaldson LJ, Jones GT: Prevalence of chronic pain in the UK: a systematic review and meta-analysis of population studies. BMJ Open. 2015, 6:e010364. 10.1136/bmjopen-2015-010364

24. Langford R, Brown I, Vickery J, Mitchell K, Pritchard C, Creanor S: Study protocol for a double blind, randomised, placebo-controlled trial of continuous subpectoral local anaesthetic infusion for pain and shoulder function following mastectomy: SUB-pectoral Local anaesthetic Infusion following MastEctomy (SUBLIME) study. BMJ Open. 2014, 14:e006318. 10.1136/bmjopen-2014-006318

25. DR Leff, C Ho, H Thomas, et al.: A multidisciplinary team approach minimises prophylactic mastectomy rates. Eur J Surg Oncol. 2015, 41:1005-1012. 10.1016/j.ejso.2015.02.017

26. Amatya B, Khan F, Galea MP: Optimizing post-acute care in breast cancer survivors: a rehabilitation perspective. J Multidiscip Healthc. 2017, 10:347-357. 10.2147/JMDH.S117362

27. Tunay VB, Akbayrak T, Kaya S: The effect of multidimensional physiotherapy program on shoulder function, pain, and lymphedema after surgery in elderly breast cancer patients. Top Geriatr Rehabil. 2012, 28:281- 
286. 10.1097/TGR.0b013e31825bbbef

28. Castro-Martín E, Ortiz-Comino L, Gallart-Aragón T, Esteban-Moreno B, Arroyo-Morales M, Galiano-Castillo $\mathrm{N}$ : Myofascial induction effects on neck-shoulder pain in breast cancer survivors: randomized, single-blind, placebo-controlled crossover design. Arch Phys Med Rehab. 2017, 98:832-840. 10.1016/j.apmr.2016.11.019

29. Olsson Möller U, Beck I, Rydén L, Malmström M: A comprehensive approach to rehabilitation interventions following breast cancer treatment - a systematic review of systematic reviews. BMC Cancer. 2019, 19:472. 10.1186/s12885-019-5648-7

30. Casla S, Hojman P, Márquez-Rodas I, López-Tarruella S, Jerez Y, Barakat R, Martín M: Running away from side effects: physical exercise as a complementary intervention for breast cancer patients. Clin Transl Oncol. 2015, 17:180-196. 10.1007/s12094-014-1184-8

31. Galantino ML, Stout NL: Exercise interventions for upper limb dysfunction due to breast cancer treatment . Phys Ther. 2013, 93:1291-1297. 10.2522/ptj.20120049

32. Hwang JH, Chang HJ, Shim YH, Park WH, Park W, Huh SJ, Yang JH: Effects of supervised exercise therapy in patients receiving radiotherapy for breast cancer. Yonsei Med J. 2008, 49:443-450. 10.3349/ymj.2008.49.3.443

33. Geneen LJ, Moore RA, Clarke C, Martin D, Colvin LA, Smith BH: Physical activity and exercise for chronic pain in adults: an overview of Cochrane Reviews. Cochrane Database Syst Rev. 2017, 2017:CD011279. 10.1002/14651858.CD011279.pub2

34. Tiengo MA: La percezione del dolore: il ruolo della corteccia frontale [Book in Italian] . Springer, 2001.

35. De La Rosa D, Torres Lacomba, Cerezo Téllez E, del Campo Gómez-Rico CD, Gutiérrez Ortega C: Accessory joint and neural mobilizations for shoulder range of motion restriction after breast cancer surgery: a pilot randomized clinical trial. J Chirop Med. 2017, 16:31-40. 10.1016/j.jcm.2016.09.001

36. Cho Y, Do J, Jung S, Kwon O: Effects of a physical therapy program combined with manual lymphatic drainage on shoulder function, quality of life, lymphedema incidence, and pain in breast cancer patients with axillary web syndrome following axillary dissection. Support Care Cancer. 2016, 24:2047-2057. 10.1007/s00520-015-3005-1

37. International Association for the Study of Pain . (2019). https://www.iasp-pain.org/.

38. Lipps DB, Sachdev S, Strauss JB: Quantifying radiation dose delivered to individual shoulder muscles during breast radiotherapy. Radiother Oncol. 2017, 122:431-436. 10.1016/j.radonc.2016.12.032

39. Edmond SN, Shelby RA, Keefe FJ, et al.: Persistent breast pain among women with histories of breastconserving surgery for breast cancer compared with women without histories of breast surgery or cancer. Clin J Pain. 2017, 33:51-56. 10.1097/AJP.0000000000000377

40. Fayaz A, Croft P, Langford RM, Donaldson LJ, Jones GT: Prevalence of chronic pain in the UK: a systematic review and meta-analysis of population studies. BMJ Open. 2016, 6:e010364. 10.1136/bmjopen-2015-010364

41. Wolin KY, Schwartz AL, Matthews CE, Courneya KS, Schmitz KH: Implementing the exercise guidelines for cancer survivors. J Support Oncol. 2012, 10:171-177. 10.1016/j.suponc.2012.02.001 